\title{
Nilai Idealisme dan Nilai Kepribadian dalam Novel Gajah Mada Karya Langit Kresna Hariadi
}

\author{
Zaeni Dahlan \\ Universitas Indraprasta PGRI \\ Jalan Nangka No. 58 C/TB. Simatupang, Tanjung Barat, Jakarta Selatan 12530
}

\begin{abstract}
The purpose of this study was to determine the value of idealism and personality values in the novel Gajah Mada by Langit Kresna Hariadi. The results of the analysis are that the values of subjective idealism are more dominant and the value of objective idealism is lower and personality values of Id are more dominant and personality values of superego are lower. Seen from seventy (70) quotations with the following details: (1) the value of subjective idealism by 28\%, (2) the value of objective idealism by 14\%, (3) the value of personal idealism by $24 \%$. Besides that there are personality values as follows: (1) Id personality value as much as 14\%, (2) ego personality value as much as 12\%, (3) superego personality value as much as $10 \%$.
\end{abstract}

Keywords: Idealism Values, Personality Values.

\begin{abstract}
Abstrak
Tujuan dalam penelitian ini adalah untuk mengetahui nilai idealisme dan nilai kepribadian dalam novel Gajah Mada karya Langit Kresna Hariadi. Hasil dari analisis ialah nilai idealisme subjektif lebih dominan dan nilai idealisme objektif lebih rendah serta nilai kepribadian Id lebih dominan dan nilai kepribadian superego lebih rendah. Terlihat dari tujuh puluh (70) kutipan dengan rincian sebagai berikut: (1) nilai idealisme subjektif sebanyak $28 \%$, (2) nilai idealisme objektif sebanyak $14 \%$, (3) nilai idealisme personal sebanyak $24 \%$. di samping itu terdapat nilai kepribadian sebagai berikut: (1) nilai kepribadian Id sebanyak $14 \%$, (2) nilai kkepribadian ego sebanyak $12 \%$, (3) nilai kkepribadian superego sebanyak $10 \%$.
\end{abstract}

Kata Kunci: Nilai Idealisme, Nilai Kepribadian

\section{PENDAHULUAN}

Rencana makar yang dituduhkan pada sekelompok golongan,menyebabkan memanasnya situasi politik yang ada di Indonesia. Belakangan ini, seorang perempuan ditangkap karena melakukan pembaptisan anaknya bertepatan dengan peringatan HUT Proklamasi Republik Maluku Selatan (RMS). Peristiwa lainnya, seorang lelaki ditangkap karena turut serta dalam acara peringatan HUT Proklamasi Kemerdekaan Negara Republik Melanesia Barat atau Papua Barat. Dalam upacara tersebut dilakukan pengibaran bendera Bintang 14, bendera negara Papua Barat.

Kejadian-kejadian tersebut tentunya bukan mencerminkan masyarakat Indonesia yang patuh dan taat pada hukum yang ada di Indonesia. Keinginan untuk keluar dari negara Indonesia, menunjukan nilai idealis dalam berbangsa dan bernegara sudah mulai pudar. Tentunya hal ini menjadi sebuah catatan bagi kita yang masih menjunjung tinggi nilai idealis sebagai negarawan dan bangsawan yang baik.

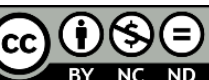

Creative Commons Attribution-NonCommercial-NoDerivatives 4.0 International License 
Keinginan dan kenyataan yang sejalan lurus adalah konsep utama dalam nilai idealisme. Terkadang keinginan itu tidak sesuai dengan realita dan kenyataan yang terjadi. Bentuk realita adalah manifestasi dalam idealisme karena pandangan sepeerti ini idealisme sering disebut sebagai lawan dari aliran realisme. Tetapi, aliran ini justru muncul atas feed back realisme yang menganggap realitas sebagai kebenaran tertinggi. Aliran ini juga mengemukakan bahwa dunia ide,dunia citacita, dunia harapan adalah dunia utama yang dituju dalam pemikiran manusia.

Karya Sastra, tak terkecuali novel, selalu dapat ditemukan nilai-nilai pendidikan yang dapat diambil manfaatnya. Salah satunya nilai idealisme dan nilai kepribadian. Satsra melalui unsur imajinasinya mampu membimbing pembaca pada kebebasan dan keluasan berpikir, bertindak, berkarya, dan sebagainya. Begitu penting keberadaan imajinasi, banyak negara barat yang meletakkan imajinasi sebagai bagian uang fundamental dalam pendidikan. Jadi, tidak berlebihan bila karya sastra dapat dijadikan media pembentuk karakter sebuah bangsa. Hal ini yang bertolak belakang terjadi di Indonesia yang belum mampu menempatkan sastra sebagai aspek fundamental dalam pendidikan.

Kegiatan penelitian dan analisis terhadap karya sastra dilakukan unuk megetahui korelasi dan relevansi dengan kehidpuan nyata yang ada dalam masyarakat. Penilitian dapat dijadikan sarana untuk mengetahui nilai-nilai yang terkandung dalam karya sastra yang pada dasarnya mencerminkan realitas kepribadian dan pembelajaran bagi pembaca. Selain itu, karya sastra dapat dijadikan medium untuk mengetahui realitas yang diolah secara kreatif oleh pengarang.

Kisah yang diangkat oleh Langit Kresna Hariadi dalam novelnya merupakan cerita tentang pemberontakan yang terjadi di Majapahit pasca meninggalnya Raja Jayanegara. Pemberontakan ini bisa dipadamkan oleh Pasukan Bhayangkara yang dipimpin oleh Gajah Mada. Kejutan dalam novel ini adalah bahwa banyak orang di belakang Raden Cakradara dan Raden Kudamerta (keduanya calon suami calon Ratu Majapahit) yang haus kekuasaan. Kedua orang tersebut seolah hanya menjadi boneka demi mendapat kekuasaan. Kejutan lain adalah kenyataan bahwa istri Ra Tanca (Ra Tanca pernah ingin makar dan telah terbunuh) yang menghimpun kekuatan untuk makar terhadap Majapahit.

Peneliti mencoba mengupas novel yang berjudul Gajah Mada karya Langit Kresna Hariadi dengan membatasi pada nilai idealisme dan nilai kepribadian. Kegiatan penelitian dan analisis ini dilakukan untuk megetahui korelasi dan relevansi dengan kehidpuan nyata yang ada dalam masyarakat. Penilitian dapat dijadikan sarana untuk mengetahui nilai-nilai yang terkandung dalam karya sastra yang pada dasarnya mencerminkan realitas kehidupaan berdasarkan idealisme kepribadian dan pembelajaran bagi pembaca.

J.H. Rapar (1996) mengemukan bahwa idealisme adalah aliran filsafat yang menekankan "idea" (dunia roh), sebagai objek pengertian dan sumber pengetahuan. Idealisme berpandangan bahwa segala sesuatu yang dilakukan oleh manusia tidaklah selalu harus berkaitan dengan hal-hal yang bersifat lahiriah, tetapi harus berdasarkan prinsip kerohanian (idea). Oleh sebab itu, idealisme sangat mementingkan perasaan dan fantasi manusia sebagai sumber pengetahuan. 


\section{Diskursus: Jurnal Pendidikan Bahasa Indonesia}

Vol. 1, No. 3, Desember 2018, pp. 293-303

p-ISSN: 2615-4935

e-ISSN: 2615-4943

Juhaya(2003) mengemukakan bahwa sejarah idealisme cukup berliku-liku dan meluas karena mencakup berbagai teori yang berlainan walaupun berkaitan. Ada beberapa jenis idealisme; yaitu idealisme subjektif, idealisme objektif, dan idealisme personal. (1) idealisme subjektif adalah filsafat yang berpandangan idealis dan bertitik tolak pada ide manusia atau ide sendiri. Alam dan masyarakat ini tercipta dari ide manusia. Segala sesuatu yang timbul dan terjadi di alam atau di masyarakat adalah hasil atau karena ciptaan ide manusia atau idenya sendiri, atau dengan kata lain alam dan masyarakat hanyalah sebuah ide/pikiran dari dirinya sendiri atau ide manusia. Salah satu tokoh terkenal dari aliran ini adalah seorang dari Inggris yang bernama George Berkeley (1684-1753 M). Menurut Berkeley, segala sesuatu yang tertangkap oleh sensasi/perasaan kita itu bukanlah materi yang real da nada secara objektif; (2) idealisme objektif adalah idealisme yang bertitik tolak pada ide di luar ide manusia. Idealisme objektif ini dikatakan bahwa akal menemukan apa yang sudah terdapat dalam susunan alam. Menurut idealisme objektif segala sesuatu baik dalam alam atau masyarakat adalah hasil dari ciptaan ide universal. Pandangan filsafat seperti ini pada dasarnya mengakui sesuatu yang bukan materi, yang ada secara abadi di luar manusia, sesuatu yang bukan materi itu ada sebelum dunia alam semesta ini ada, termasuk manusia dan segala pikiran dan perasaannya. (3) idealisme personal dikelompokkan yang didasarkan atas perbedaan dalam kemampuan rohani yang diutamakan, yaitu apakah pikiran, perasaan, ataukah kehendak. Dengan demikian macam-macam pengelompokan aliran idealisme dibagi menjadi tiga, yaitu idealisme rasionalistik, idealisme estetik, idealisme etik.

Kkepribadian dipandang sebagai sebuah struktur yang terdiri dari tiga struktur atau sistem, yakni id, ego, dan superego. Ketiga sistem tersebut merupakan instansi yang menandai hidup psikis dan saling berkaitan serta membentuk suatu totalitas. Koswara (1991: 32-34) mengatakan, Tingkah laku manusia tidak lain merupakan produk interaksi antara $i d$, ego dan superego.

$I d$ (dalam istilah Freud: das es) adalah sistem kepribadian yang paling dasar yang di dalamnya terdapat naluri-naluri bawaan. Untuk dua sistem lainnya, id adalah sistem yang bertindak sebagai penyedia atau penyalur energi yang dibutuhkan oleh sistem-sistem tersebut untuk operasi-operasi atau kegiatankegiatan yang dilakukan. Id tidak bisa menoleransi penumpukan energi yang bisa menyebabkan meningginya taraf ketegangan organisme atau menyenangkan bagi individu. Id akan selalu ketaraf semula. Sedangkan (Koswara, 1991: 33) berpendapat, dalam menjalankan fungsi dan operasinya, $I d$ dilandasi oleh maksud mempertahankan konstansi (the principle of contancy) yang ditujukan untuk menghindari keadaan yang tidak menyenangkan dan mencapai keadaan yang menyenangkan (the pleasure principle).

Untuk mencapai maksud tujuannya, id memiliki perlengkapan berupa dua macam proses. Proses pertama berupa tindakan reflek, yakni suatu bentuk tingkah laku atau tindakan yang mekanisme kerjanya otomatis dan segera serta adanya pada individu merupakan bawaan. Proses kedua adalah proses primer, yakni suatu proses yang melibatkan sejumlah reaksi psikologis yang rumit. Dalam proses ini, id berusaha mengurangi tegangan dengan cara membentuk bayangan dari objek yang

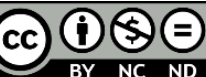

Creative Commons Attribution-NonCommercial-NoDerivatives 4.0 International License 
bisa mengurangi tegangan. Bagi id, objek yang dihadirkan dalam proses primer itu nyata namun bagaimana pun dalam realitas objek itu tetap tidak akan sungguhsungguh mengurangi tegangan. Individu masih membutuhkan sistem lain yang bisa mengarahkan kepada pengurangan tegangan secara nyata atau sesuai dengan kenyataan. Sistem ini tidak lain adalah ego namun demikian id tidak terpengaruh kontrol ego.

Ego (dalam istilah freud: Das Ich) adalah sistem yang bertindak sebagai pengarah individu kepada dunia objek dari kenyataan, menjalankan fungsinya berdasarkan prinsip kenyataan, dan menjalankan fungsinya berdasarkan kenyataan (the reality principle). Ego terbentuk dari deferensial id karena kontaknya dengan dunia luar. Proses yang dijalankan ego sehubungan dengan upaya memuaskan kebutuhan atau mengurangi ketegangan adalah proses. Sekunder (secondary proses). Dengan proses sekundernya ini ego memformulasikan rencana pemuasan kebutuhan dan menguji apakah rencana tersebut bisa dilaksanakan atau tidak. Ego tidak hanya bertindak sebagai petunjuk kepada kenyataan tetapi juga berperan sebagai penguji kenyataan (reality tester) (Koswara, 1991: 34). Ego memainkan peranannya dengan melibatkan fungsi psikologis yang tinggi yakni fungsi kognitif dan intelektual.

Tugas ego adalah mempertahankan kepribadian dan menjamin penyesuaian dengan dunia luar. Ego dalam menjalankan fungsinya ditunjukkan untuk menghambat pemuasan kebutuhan atau naluri yang berasal dari id melainkan bertindak sebagai perantara dari tuntunan-tuntunan naluriah organisme di satu pihak dengan keadaan lingkungan di pihak lain. Yang dihambat oleh ego adalah pengungkapan naluri yang tidak layak atau yang tidak dapat diterima oleh lingkungan. Jadi, fungsi yang paling dasar dari ego adalah pemeliharaan kelangsungan hidup dari individu dan menjalankan kesatuan kepribadian (Freud dalam Koswara, 1991: 11).

Dalam penelitian ini, peneliti akan memaparkan temuan-temuan data berdasarkan pesan secara umum, mewacanakannya dan mendeskripsikan kalimatkalimat yang memiliki muatan-muatan sebagai aspek tersebut. Terkait dengan hal tersebut maka, mengetahui aspek kepribadian tersebut, terlebih dahulu peneliti akan mendeskripsikan pesan-pesan secara umum berdasarkan analisis teks.

Pengarang menyampaikan idealisme melalui novelnya antara lain semangat nasionalisme yang memiliki tokoh-tokoh dalam cerita yang diharapkan dapat membuka pikiran pembaca untuk selalu berjuang untuk selalu berjuang untuk mewujudkan kesejahteraan hidupnya dan bangsanya.

Aspek kepribadian yang mengandung tiga kategori dapat pengarang gambarkan dalam novel Gajah Mada yaitu id, ego, dan superego. Dengan harapan agar pembaca dapat menghayati dan mengambil pelajaran dari apa yang telah dibaca. Novel ini juga memberikan deskripsi lengkap tentang persoalan psikologi, sosial dan budaya saat itu.

Berdasarkan fenomena-fenomena yang terjadi di atas telah menggambarkan keadaan pada saat ini dan membuat para sastrawan tertarik untuk menganalisis fenomena-fenomena tersebut. 
Novel Gajah Mada karya Langit Kresna Hariadi. Diterbitkan oleh PT. Tiga Serangkai Pustaka Mandiri Solo, 2017. Novel ini terdiri dari 44 bab dan terdapat 508 halaman. Pada halaman belakang bagian novel ini tertulis tentang penulis.

\section{METODE}

Metode dalam penelitian ini menggunakan metode kualitatif. Metode ini mengacu pada deskripsi data berupa kalimat-kalimat yang terdapat pada novel Gajah Mada Karya Langit Kresna Hariadi. Data pada kalimat yang diambil adalah deskripsi paparan pengarang novel Gajah Mada Karya Langit Kresna Hariadi. Nilai idealisme yang menjadi fokus penelitian meliputi idealisme subjektif, idealisme objektif, dan idealisme personal. Nilai kepribadian meliputi unsur id, ego, dan superego.

Fokus dalam penelitian ini yang dibahas adalah nilai idealisme dan nilai kepribadian yang terdapat dalam novel Gajah Mada karya Langit Kresna Hariadi. Subfokus Fokus peneltian ini dikembangkan menjadi dua subfokus penelitian, yaitu: (1) Struktur (tokoh, alur, latar, dan tema,) dalam novel Gajah Mada karangan Langit Kresna Hariadi.

Penelitian dilakukan dengan menggunakan instrumen berbentuk tabel analisis. Tabel tersebut ialah tabel mengenai kelainan identitas gender yang dideskripsikan ke dalam unsur kepribadian Sigmund Freud. Instrumen penelitian ini adalah peneliti sendiri (human instrument) yang dibantu dengan tabel analisis, bertujuan untuk mengumpulkan dan mengolah data-data sehingga dapat mempermudah peneliti dalam menganalisis serta mendeskripsikan analisis aspek idealisme dan aspek kepribadian dalam novel Gajah Mada Karya Langit Kresna Hariadi.

Teknik analisis data yang digunakan dalam penelitian ini dilakukan secara deskriptif dengan analisis isi (conten analysis) yaitu dengan menganalisis korpus yang terpilih pada setiap sampel.

Secara terperinci, langkah-langkah analisis data yang dilakukan adalah: 1) Menganalisis isi novel secara keseluruhan. 2) Menentukan paragraf-paragraf yang akan dianalisis dengan mereduksi sepertiga dari jumlah paragraf pada bab yang terpilih. 3) Menganalisis aspek idealisme dan aspek kepribadian yang terdapat dalam paragraf sesuai dengan indikatornya. 4) Mengklasifikasi aspek idealisme dan aspek kepribadian yang ditemukan ke dalam tabel kerja. 5) Mempresentasikan temuan dan menyimpulkan hasil penelitian. 6) Mengkategorisasi tabel berdasarkan fokus penelitian. 7) Menjelaskan secara deskriptif hasil kategori tabel analisis. 8) Menyimpulkan hasil penelitian

Dalam menganalisis novel, penulis mengacu pada unsur psikologis dan sosiologi yang merupakan unsur ekstrinsik dalam karya sastra, untuk memeroleh hasil yang maksimal penulis tidak menambahkan unsur-unsur lain seperti psikologi, politik, ekonomi ke dalam penelitian ini. Teknik keabsahan data penelitian ini diperoleh dengan cara membandingkan tinjauan nilai sosiologi dengan komunikasi, adaptasi, persuasi, harmoni, dan konflik. Berdasarkan data penelitian yang diperoleh dari jumlah unsur dominan yang menjadi keabsahan datanya. Selain itu,

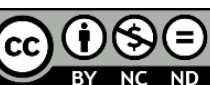

Creative Commons Attribution-NonCommercial-NoDerivatives 4.0 International License 
pendekatan ini menggunakan penelitian sebagai basis pengumpulan data, bersifat mencari dan menemukan. Pendekatan teoretik sangat membantu penulis memeroleh pemahaman data, memilih data..

\section{HASIL DAN PEMBAHASAN}

Penelitian ini mencoba memunculkan nilai idealisme yang terkandung dalam Gajah Mada. Data yang didapatkan berdasarkan data dipilih secara acak berdarkan urutan peristiwa dalam novel serta halaman. Adapun aspek yang diambil meliputi idealisme subjektif, idealisme objektif, dan idealisme personal. Berikut temuan yang didapatkan:

\section{Temuan dari kutipan 1}

Kala itu, tahun 1309. Segenap rakyat berkumpul di alun-alun. Semua berdoa, apa pun warna agamanya, apakah siwa, Budha maupun Hindu. Semua arah perhatian ditujukan dalam satu pandang, ke Purwakarta yang tidak dijaga terlampau ketat. Segenap prajurit bersikap ramah kepada siapa pun karena memang demikian sikap keseharian mereka. Lebih dari itu, segenap prajurit merasakan gejolak yang sama, oleh duka mendalam atas gering yang diderita Kertarajasa Jayawardhana (Gm:1)

Dari uraian di atas dapat disimpulkan bahwa zaman kerajaan seperti diatas, semunya bersatu padu atas kesedihan dan luka yang diderita rajannya. Mereka menanggalkan egonya masing-masing untuk kepentingan bersama.

2. Temuan dari kutipan 2

Pintu yang kemudian terbuka adalah untuk memberi kesempatan kepada Arya Tadah, Mahapatih Majapahit yang ingin mengetahui bagaimana keadaan rajanya. Tadah datang saat yang tepat. Arya Tadah tidak datang terlambat untuk sekadar menjadi saksi. Bergegas Arya Tadah yang tua itu mendekat, gemetar tangannya menyentuh kaki Sang Prabu (GM:14)

Dari uraian di atas dapat disimpulkan bahwa hormat dan patuh kepada sang raja dilakukan dengan tulus dan dari hati yang dalam. Ketika bertemu pun tunduk dan patuh sebagai hamba untuk Sang Prabu.

Dari dua uraian di atas dapat disimpulkan bahwa idealisme subjektif yang bersumber dari ide lain adalah tentang rencana makar yang terjadi pada zaman Kerajaan Majapahit untuk perebutan kekuasan pimpinan pada saat itu.

3. Temuan dari kutipan 21

Duka membayang di kaki langit, duka sekai lagi membungkus Majapahit. Ada banyak hal yang dicatat Pancaaksara, banyak sekali. Kesedihan kali ini terjadi bagai pengulangan peristiwa sembilan belas tahun yang lalu, yang ditulisnya berdasar kisah yang dituturkan ayahnya, Samenaka, karena 
ketika peristiwa itu terjadi Pancaksara belum bisa dibilang dewasa. (GM:1)

Peristiwa di atas menggambarkan tentang kesediahan yang dirasakan oleh rakyat, kesediihan tersebut menyelimuti seluruh jagat kerjaan Majapahit. Semuanya merasakan kesedihan bukan hanya dari pihak istana saja. Hal ini tentunya menggambarkan bahwa rasa saling berbagi dalam kehidupan sosial.

4. Temuan dari kutipan 22

Gajah Mada terbangun dari bingungnya ketika Ratu Rajapatni Biksuni Gayatri yang berdiri bersebelahan dengan Mahapatih Arya Tadah menyentuh tangannya. Gajah Mada segera mengambil sikap dan memberikan penghormatan. (GM:15)

Peristiwa di atas menggambarkan tentang kerajaan yang memegang teguh rasa saling menghormati dan patuh sesama para petinggi dari kerajaan tersebut. Semuanya saling menjaga etika dalam beprilaku.

Dari dua uraian diatas dapat disimpulkan bahwa idealisme Objektif adalah idealisme yang bertitik tolak pada ide di luar ide manusia. Idealisme objektif ini dikatakan bahwa akal menemukan apa yang sudah terdapat dalam susunan alam

\section{Temuan dari kutipan 31}

Racun yang diminumkan kepada Raja Majapahit itu tentu merupakan jaminan, korban tak mungkin selamat. Namun, Gajah Mada tidak mau menyerah. Meski tidak seperti Ra Tanca yang amat menguasai ilmu pengobatan, walau sedikit Gajah Mada memahami bagain-bagian paling sederhana, seperti tindakan apa yang harus dilakukan untuk menawarkan raccun yang terlanjur masuk ke tubuh. Perintah diberikan kepada seorang prajurit untuk segera mencari kelapa muda dari jenis degan ijo yang diyakini mampu menawarkan berbagai jenis racun dengan menyerapnya.(GM:11)

Dari uraian di atas dapat disimpulkan bahwa pengorbanan dan usaha dilakukan untuk melindungi dan menyelamatkan Raja Majapahit. Hal itu merupakan bentuk kesetian dan kecintaan para abdi dalem dan rakyat terhadap raja yang mereka hormati.

6. Temuan dari kutipan 32

Di depan Balai Witana atau dari tempat itu arah pandang menjuju utara yang hanya berjarak puluhan langkah kaki saja adalah tempat Penagkilan, tempat duduk para pujangga dan menteri. Di bagian timur menghaadap ke Balai Witana adalah tempat berkumpul para pendeta Siwa dan Budha. (GM:11)

Dari uraian di atas dapat disimpulkan bahwa balai atau gazibu telah ada dari dulu diajdikan untuk pertemuan besar dan juga dijadikan tempat diskusi 
serta bertukar pikiran untuk bermusyawarah.

Dari dua uraian diatas dapat disimpulkan bahwa idealisme personal adalah nilai-nilai perjuangannya untuk menyempurnakan dirinya. Personalisme muncul sebagai protes terhadap materialisme mekanik dan idealisme monistik.

7. Temuan dari kutipan 46

Segenap kawula yang mencintai rajanya memang amat berharap raja akan sembuh dan kembali memimpin negara menuju kejayaan yang lebih bercahaya dan cemerlang. Akan tetapi, Hyang Widdi mempunyai kehendak lain. Napas Sang Prabu makin tersenggal tarikannya kian tersendat, kesadarannya makin berkurang seiring sakit yang diderita yang tak tersembuhkan. Para tabib yang didatangkan untuk menyembuhkan Sang Prabu angkat tangan tanda menyerah. (GM:4)

Dari uraian di atas dapat disimpulkan bahwa harapan dan keinginan hidup bahagia adalah hal naluriah. Semua orang ingin hidupnya dalam keadaan tentram, aman, dan nyaman. Namun kadang harapan itu tidak sesuai dengan kenyataan yang ada.

8. Temuan dari kutipan 47

Puncak kekuasaan kemudian berhasil ia peroleh, sekaligus menjadi awal kemelut berkepanjangan dan berdarah-darah. Ken arok menjadi raja pertama Singasari, beribu kota di Tumapel muali 1222 hinggs 1227, dalam waktu hanya lima tahun.. (GM:28)

Dari uraian di atas dapat disimpulkan bahwa haus kekuasaan menjadi hal yang lumrah. Kekuasaan bagaikan mutiara yang diperebutkan. Kekuasaan bukan lagi sebagai amanah yang harus dipikul oleh seorang pemimpin. Melainkan alat dan harta untuk kebahagian hidup pribadinya.

Dari dua uraian diatas dapat disimpulkan bahwa nilai kepribadian id adalah sistem yang bertindak sebagai penyedia atau penyalur energi yang dibutuhkan oleh sistem-sistem tersebut untuk operasi-operasi atau kegiatankegiatan yang dilakukan.

9. Temuan dari kutipan 56

Raden Wiajya yang berhasil memanfaatkan tentara dari Mongol untuk mengilas Jayakatwang, mendadak melakukan tikaman ketika pasukan Mongol tidak siap, dan sisanya kembali berlayar pulang ke negerinya. (GM:30)

Dari uraian di atas dapat disimpulkan bahwa seorang pemimpin yang mempunyai dan memahami strategi dalam berperang membuat kokoh dan menang dalam peperangan. Hal ini tentunya berdasarkan pengalaman. 


\section{Temuan dari kutipan 57}

Orang pertama yang rupanya berada pada pihak yang memberi perintah untuk melakukan pembunuhan itu terdiam. Cukup lama orang itu membeku sambil menatap bintang-bintang di langit, seperti mencari sesuatu di atas sana, sesuatu yang dicari itu tidak diketemukan . (GM:61)

Dari uraian di atas dapat disimpulkan bahwa ketika seseorang ketahuan berbuat kejahatan mereka akan melakukan hal-hal yang tidak biasanya ia lakukan. Rasa gugup yang tidak bisa ditutupi membuatnya membongkar aibnya sendiri.

Dari dua uraian diatas dapat disimpulkan Ego adalah sistem yang bertindak sebagai pengarah individu kepada dunia objek dari kenyataan, menjalankan fungsinya berdasarkan prinsip kenyataan, dan menjalankan fungsinya berdasarkan kenyataan (the reality principle).

11. Temuan dari kutipan 65

Istana yang dijarah telah dikembalikan, dampar kencana kembali diduduki Sri Jayanegara, yang pada namanya melekat abiseka Sri Sundarapandyawardana. Setelah rakuti melakukan makar, kalagemt berjuang sekuat tenaga memulihkan luka-luka lama, bekerja keras mengembalikan kemakmuran dan kesejahteraan rakyatnya. (GM:8)

Dari uraian di atas dapat disimpulkan bahwa yang hak akan kembali pada haknya. Sesuatu yang bukan haknya tidak akan lama dalam genggamannya.

\section{Temuan dari kutipan 67}

"Lantas soal istri Ra Tanca, Gajah Mada Menambah, "Bagaimana kebenaranny, apakah ia memang benar-benar diganggu Sang Prabu? Jawbanya berupa pernyaan yang aku berikan epadamu. Apakah jika orang membicaraan seseorang, apa yang dibicarakannya itu pasti benardan mewakili kenyataan. (GM:47)

Dari uraian di atas dapat disimpulkan bahwa fakta dan opini itu tipis bedanya. Kecurigaan seseorang terhadap sesuatu adalah hal yang wajar. Namun dalam penyelesaiannya hendaklah saling mendengarkan penejelasan bukan hanya dari satu pihak saja. Tetapi bisa dari dua belah pihak.

Dari dua uraian diatas dapat disimpulkan bahwa Superego adalah sistem kepribadian yang berisi nilai dan aturan yang sifatnya evaluatif. Superego terbentuk melalui internalisasi nilai atau aturan dalam diri individu dari orang lain yang diolah sedemikian rupa sehingga akhirnya terpancar dari dalam. 


\section{SIMPULAN}

Berdasarkan hasil penelitian yang telah dilakukan pada nilai idealisme dan nilai kepribadian novel Gajah Mada Karya Langit Kresna Hariadi maka dapat diketahui. (1) Nilai idealisme subjektif lebih dominan dan niali idealisme objektif lebih rendah dalam novel Gajah Mada karya Langit Kresna Hariadi, (2) Nilai kepribadian Id lebih dominan dan nilai kepribadian superego lebih rendah.

Novel Gajah Mada karya Langit Kresna Hariadi memiliki sebuah potret kehidupan dan novel yang memiliki nilai historis tentang rencana makar yang dilakukan sebagian orang untuk merebut kekuasaan di pemerintahan. Novel ini mengajarkan betapa pentingnya saling rukun antar warga negara. Makar adalah tindakan melawan keputusan pemerintahan secara masif dan terstruktur. Oleh karena itu, dilakukan analisis tentang idealisme dan kepribadian untuk mengetahui kesesuaian yang ada dalam novel tersebut. Semua hal ini tentunya merupakan nilainilai yang terkandung dalam novel yang layak dijadikan sebuah pesan yang sangat bermakna bagi pembacanya.

Novel Gajah Mada karya Langit Kresna Hariadi mempunyai beberapa sisi kelebihan dari novel yang lainnya, yaitu merupakan novel yang memiliki aspek idealisme. Novel ini adalah novel yang segmen pembacanya masuk ke dalam semua kalangan dan di dalamnya mengandung hakikat dalam kehidupan. Bukan hanya kalangan akademisi saja, melainkan juga untuk kalangan lainnya. Aspek lain yang menjadi pembeda adalah, adanya nilai historis keadaan Bangsa Indonesia kurang lebih ratusan abad yang lalu. Aspek yang lain pun banyak diuraikan dalam bagian alur cerita yang membangun, seperti pada unsur idealisme subjektif, idealisme objektif, dan idealisme personal yang banyak membahas kehidupan masyarakat dengan segala macam problematika dengan lingkungannya.

\section{DAFTAR PUSTAKA}

Aminuddin. (2002). Pengantar apresiasi sastra. Bandung: Sinar Baru Algesindo. Arifin, E. Z. (2008). Dasar-dasar penulisan karya ilmiah. Jakarta: Grasindo.

Ihsan, A. F. (2010). Filsafat ilmu. Jakarta: Rineka Cipta.

J.H. Rapar. 1996. Filsafat Politik Plato.Jakarta: Rajawali Press

Juhaya S Praja. 2003. Aliran-aliran Filsafat \& Etika. Jakarta: Fajar IInter Pratama. Kosasih, E. (2012). Dasar-dasar keterampilan bersastra. Bandung: Yrama Widya. Nurgiyantoro, B. (2009). Teori pengkajian fiksi. Yogyakarta: Gadjah Mada University Press.

Pradopo, R. D. (2007). Prinsip-prinsip kritik sastra. Yogyakarta: Gajah Mada University Press.

Ratna, N. K. (2012). Penelitian sastra. Yogyakarta: Pustaka Pelajar.

Sudarsono. (2008). Ilmu filsafat. Jakarta: Rineka Cipta.

Sugiyono. (2012). Metode penelitian pendidikan. Bandung: Alfabeta.

Sumaryoto. (2015). Panduan penulisan skripsi, tugas akhir, dan tesis. Jakarta: Unindra Press.

Waluyo, H. J. (2002). Apresiasi Puisi. Jakarta: Gramedia Pustaka Utama. 
Diskursus: Jurnal Pendidikan Bahasa Indonesia

Vol. 1, No. 3, Desember 2018, pp. 293-303

p-ISSN: 2615-4935

e-ISSN: 2615-4943

Minderop, A. (2010). Psikologi Sastra. Jakarta: Gramedia Pustaka Utama.

Sudjiman, P. (1991). Memahami Cerita Rekaan. Jakarta: Pustaka Jaya.

Moleong, L. J. (2007). Metodologi Penelitian Kualitatif. Bandung: Remaja Rosdakarya.

Wellek, R., \& Warren, A. (1995). Teori Kesusastraan. Jakarta: PT Gramedia Pustaka Utama. 